\title{
THE ROLE OF BETA-BLOCKERS IN VETIANGINAL THERAPY IN THE CORRECTION OF VIOLATIONS OF THE AMINO ACID SPECTRUM IN PATIENTS WITH UNSTABLE ANGINA WITH CONCOMITANT DIABETES MELLITUS*
}

\author{
Bohdan T. V., Lizogub V. G., Sobol V. O., Bohdan V. V. \\ Bogomolets National Medical University, Kyiv, Ukraine \\ taviza@mail.ua
}

\begin{abstract}
Despite significant achievements in the diagnosis and treatment of coronary heart disease (CHD) in recent years, this pathology remains a leader in the structure of morbidity and mortality among the population of Ukraine. A special role belongs to acute forms of coronary heart disease (non-stable angina (NA) and myocardial infarction) [1]. Atherosclerosis in diabetes mellitus (DM) develops 10-15 years earlier and has a more aggressive course than in the non-diabetic population. Mortality from cardiovascular diseases in patients with diabetes is $2-3$ times higher, and life expectancy is reduced by $10-30 \%$ [2-4].

In this regard, the processes of peroxidation, inflammatory activation, vascular dysfunction as potential mechanisms influencing the increase in cardiovascular risk in the presence of diabetes continue to study.
\end{abstract}

Today, various links in the pathogenesis of atherosclerosis and coronary heart disease (dyslipidemia, endothelial dysfunction, impaired immunological status, exposure to infection, violation of the rheological properties of blood) have been identified and substantiated. Over the last decade, the study of amino acid balance (AA) disorders in blood plasma, as another possible pathogenetic link in the development of coronary heart disease, has attracted the attention of scientists and clinicians [5-7].

AA are key nutrients needed for cell growth and function. They act as «bricks» not only for protein synthesis but also for many other components of the body and are a source of nitrogen and carbon [8].

Some cardioprotective properties of AA in cardiovascular pathology are described today. However, the mechanisms the influence of AA

* The article is a fragment of the research work of the Department of Internal Medicine № 4 (Head of the Department, MD, Professor Lyzogub VG) registration state number is 0117 U006000 «Hemodynamic disorders, coronary circulation and ectopic myocardial activity in patients with coronary heart disease with concomitant diabetes mellitus, methods of drug correction»"

Institution, which financed the research: Ministry of Health of Ukraine.

The authors assume responsibility for the published work.

The authors guarantee absence of competing interests and their own financial interest when carrying out the research and writing the article.

The manuscript was received by the editorial staff 12.03.2021. 
on energy metabolism processes, as well as other possible ways of influence, which provide better adaptation of the heart to hypoxia, remain unexplored [9-11].

The B-blockers remain the basic drugs for the treatment of coronary heart disease. For many years they have been used to treat stable angina, NA and myocardial infarction. The mechanism of antianginal action of these drugs is associated with a decrease in heart rate, myocardial contractility and a decrease in systolic blood pressure [12].

In addition to the already known mechanisms of action of $B$-blockers, the property of nebivolol to promote the release of nitric oxide (NO), which is one of the most important mediators functionally involved in various biological processes, is noteworthy [13]. Previous studies have shown that patients with stable and unstable coronary heart disease develop an imbalance of ACS in blood plasma [14, 15]. Therefore, it would be appropriate to determine the place of $B$-blockers in the composition of antianginal therapy and correction of these disorders in patients with NA with concomitant diabetes.

The aim of the study: to study the effect of bisoprolol and nebivolol on the spectrum of AA in blood plasma in patients with NA with concomitant type 2 diabetes in order to optimize drug treatment of this pathology.

\section{MATERIAL AND METHODS}

It was examined 70 patients (29 men (41.5\%) and 41 women (58.5\%) aged 62-73 years (mean age -65.2 years \pm 6.7 years) NA with concomitant DM type 2 . The 42 patients $(60 \%)$ had diabetes for $13.30 \pm 1.32$ years, the 28 patients $(40 \%)$ had diabetes for $14.20 \pm 1.58$ years.

Patients had such comorbidities: alimentary obesity I-II degree in 31 patients (42.3\%), osteoarthritis of the knee and hip joints in 48 patients $(68.6 \%)$, non-alcoholic steatohepatitis in 27 patients (38.6\%) and major diabetic complications: first-degree encephalopathy in 16 patients (23\%), second-degree encephalopathy in 40 patients (57\%), retinopathy in 46 patients (66\%), polyneuropathy in 52 patients $(74 \%)$, angiopathy in 57 patients $(82 \%)$. All patients were in a state of compensation of carbohydrate metabolism ( $\mathrm{Hbc1}$ did not exceed $7.0 \%$, blood glucose after fasting did not exceed $6.5 \mathrm{mmol} / \mathrm{l})$.

All patients were divided into two groups: Group I (37 patients (14 men (38\%) and 23 women $(62 \%))$ in basic therapy received bisoprolol, enalapril, atorvastatin, acetylsalicylic acid, isosorbide dinitrate, fandoparinux sodium subcutaneously, group II (33 patients (15 men $(45.5 \%)$ and 18 women (54.5\%)) received nebivolol, enalapril, rosuvastatin, acetylsalicylic acid, isosorbide dinitrag, fandoparinux sodium subcutaneously. All patients received hypoglycemic therapy - metformin (34.5\%), glibenclamide (21 persons (30\%), gliclazide (15 persons $(21.5 \%))$. The control group (CG) included
18 persons (10 men (55.6\%) and 8 women) $(44,4 \%))$ at the age of 58 - 63 years (mean age 60.1 years \pm 2.4 years)), who do not suffer from diabetes, do not have disorders of the functional state of the thyroid gland, there were healthy individuals. Examination of patients was performed at the beginning of treatment and after 20 days.

Determination of AK plasma of patients was performed by ion-exchange liquid-column chromatography on an automatic analyzer AK T-339 produced by «Microtechna» (Czech Republic, Prague) at the Institute of Biochemistry of Ukraine named after OV Palladin. Identified essential AK: arginine, valine, histidine, isoleucine, leucine, lysine, methionine, threonine, phenylalanine.

Before all study procedures were performed, all patients gave written informed consent to participate in it. The clinical trial followed the safety measures envisaged in such cases for the patient's health, protection of human rights, human dignity and moral and ethical standards in accordance with the principles of the Helsinki Declaration of Human Rights (1964), the Council of Europe Convention on Human Rights and Biomedicine, laws of Ukraine, permission of the commission on medical ethics of NMU named after OO Bogomolets.

Statistical processing of the study results was performed in "MSExelXP» and SPSS-17 for Window. Student's parametric criterion was used to assess intergroup differences. The dif- 
ference at $\mathrm{P}<0.05$ was considered significant. The results are given as $\mathrm{M} \pm \mathrm{m}$. The percentile method was established to establish standards for individual biochemical parameters.

\section{RESULTS AND THEIR DISCUSSION}

In patients with NA with concomitant DM type 2 of both groups, the amount of essential AA in blood plasma decreased significantly compared with CG by $29.4 \%$ and $28.5 \%$, respectively, and with a pre-treatment rate of $19.1 \%$ and $21,2 \%$, respectively. The results of the study are shown in table 1.

In patients of the both study groups under the influence of basic therapy with the inclusion of bisoprolol and nebivolol in the blood plasma showed a significant decrease in lysine content compared to CG, respectively, $22.8 \%$ and $19.5 \%$ as well as compared to treatment, respectively at $37.5 \%$ and $32.2 \%$. Lysine is involved in the formation of collagen, strengthening the vascular wall, in the formation of carnitine, promotes the utilization of fatty acids for the energy potential of cells and the preservation of the body's immune reactivity [5]. Reduction of lysine in blood plasma in conditions of destabilization of coronary circulation on the background of treatment with B-blockers can be considered as a compensatory reaction with increased intracellular metabolism of this AA.

In patients of group II, whose basic therapy included nebivolol, histidine remained at normal levels, which ensures the physiological course of transformations of this AA. Histidine has a vasodilating effect, normalizes blood lipid composition, is one of the most important regulators of blood clotting factors (glycoprotein and C-protein. Histidine is formed from histidine, which, along with other properties, helps to decrease blood pressure by dilatation of blood vessels) [16].

It is noteworthy that the level of methionine has decreased significantly in blood plasma by $51 \%$ and $43 \%$, respectively, on the background of bisoprolol and nebivolol treatment in both groups of patients compared with healthy individuals. L-carnitine is endogenously synthesized from methionine. Despite the fact that the synthesis of L-carnitine occurs in the liver and

Table 1

\section{Spectrum of essential AA of blood plasma \\ n patients with NA with concomitant DM type 2 on the background of treatment with bisoprolol and nebivolol, $\mathrm{\mu} / \mathrm{mol} / \mathbf{1 0 0} \mathrm{ml},(\mathrm{M} \pm \mathrm{m})$}

\begin{tabular}{c|c|c|c|c|c}
\hline \multirow{2}{*}{ Indicator } & \multirow{2}{*}{$\mathbf{C G} \mathbf{n}=\mathbf{1 8}$} & \multicolumn{2}{|c|}{ Before treatment } & \multicolumn{2}{c}{ After treatment } \\
\cline { 3 - 6 } & & $\begin{array}{c}\text { I group, } \\
\mathbf{n}=\mathbf{3 7}\end{array}$ & $\begin{array}{c}\text { II group, } \\
\mathbf{n = 3 3}\end{array}$ & $\begin{array}{c}\text { Bisoprolol }, \\
\mathbf{n}=\mathbf{3 7}\end{array}$ & $\begin{array}{c}\text { Nebivolol, } \\
\mathbf{n}=\mathbf{3 3}\end{array}$ \\
\hline Lysine & $21,98 \pm 1,50$ & $27,15 \pm 1,4^{*}$ & $26,12 \pm 1,5^{*}$ & $16,97 \pm 1,02^{*} \#$ & $17,7 \pm 1,3^{*} \#$ \\
\hline Histidine & $10,51 \pm 1,28$ & $10,66 \pm 0,9$ & $11,46 \pm 0,8$ & $7,87 \pm 0,70^{*} \#$ & $9,96 \pm 0,09 \&$ \\
\hline Arginine & $8,34 \pm 0,35$ & $8,89 \pm 0,43$ & $8,78 \pm 0,32$ & $9,2 \pm 0,39$ & $8,52 \pm 0,08$ \\
\hline Threonine & $17,4 \pm 1,37$ & $14,27 \pm 1,06^{*}$ & $14,57 \pm 1,08^{*}$ & $13,21 \pm 1,04^{*}$ & $7,64 \pm 0,53^{*} \# \&$ \\
\hline Valine & $29,03 \pm 2,42$ & $19,18 \pm 0,92^{*}$ & $18,58 \pm 1,02^{*}$ & $18,64 \pm 1,73^{*}$ & $24,97 \pm 1,09^{*} \& \&$ \\
\hline Methionine & $3,43 \pm 0,07$ & $2,15 \pm 0,05$ & $2,24 \pm 0,06$ & $1,68 \pm 0,09^{*}$ & $1,95 \pm 0,04^{*}$ \\
\hline Isoleucine & $7,25 \pm 0,42$ & $4,77 \pm 0,45^{*}$ & $4,85 \pm 0,55^{*}$ & $5,07 \pm 0,37^{*}$ & $3,22 \pm 0,07^{*} \&$ \\
\hline Leucine & $14,34 \pm 1,26$ & $10,64 \pm 0,85^{*}$ & $11,75 \pm 0,76^{*}$ & $8,41 \pm 0,57^{*} \#$ & $6,54 \pm 0,07^{*} \#$ \\
\hline Phenylalanine & $8,46 \pm 0,35$ & $7,93 \pm 0,33$ & $7,47 \pm 0,41$ & $4,68 \pm 0,27^{*} \#$ & $5,8 \pm 0,06^{*} \#$ \\
\hline Ammonia & $24,8 \pm 1,35$ & $19,0 \pm 1,02^{*}$ & $18,6 \pm 1,07^{*}$ & $20,58 \pm 0,87$ & $24,5 \pm 9,6 \# \&$ \\
\hline Sum & $120,74 \pm 7,4$ & $105,64 \pm 7,13^{*}$ & $109,56 \pm 7,78^{*}$ & $85,73 \pm 5,2$ & $86,31 \pm 4,2^{*} \#$ \\
\hline
\end{tabular}

Notes.

* significant difference in relation to the control group;

\# significant difference in terms of indicators for treatment;

\& a significant difference between groups of patients. 
kidneys, it is transported to all organs and tissues. $97 \%$ of it is found in skeletal muscle and myocardium, in tissues that use fatty acids as the main source of energy. An important function of L-carnitine is the role of the "shuttle" in the formation of acetyl-CoA from fatty acids. B-oxidation of fatty acids and the formation of ATP in the Krebs cycle occurs in mitochondria. In addition, L-carnitine helps to reduce triglycerides, total cholesterol, low-density lipoprotein cholesterol level in the blood [17].

L-carnitine is effectively used in the treatment of cardiovascular diseases, in particular, it is prescribed to patients with coronary heart disease as an antiarrhythmic agent in various variants of cardiomyopathy. L-carnitine is one of the components of blood clotting factors [7].

The significant changes in the content of AA with a branched side chain (BCAAs (valine, leucine and isoleucine)) were identified on the background of treatment. In particular, under the influence of nebivolol, the level of valine in blood plasma significantly increased compared to pre-treatment by $34.4 \%$. The level of plasma isoleucine in both study groups of patients after treatment remained significantly lower compared with CG. However, it is noteworthy that against the background of nebivolol treatment, the isoleucine content became significantly lower than after bisoprolol treatment by $35.9 \%$. Apparently, this is due to the increased metabolism of this amino acid in conditions of destabilization of the coronary circulation.

BCAAs are characterized by a tonic effect on the heart, which has been proven in both animals and humans. BCAAs have been shown to promote mitochondrial biogenesis in the myocardium and other muscles by preventing oxidative stress. Amino acids are important precursors of the components of the tricarboxylic acid cycle.

Infusion of BCAAs stimulates myocardial resuscitation as much as BCAAs, as well as ketoacid mixtures in proportion, which results in the concentration in the circulatory bed. Myocardial deprivation of BCAAs is often associated with the type of amino acids, it is simple to reduce the anabolic infusion of BCAAs on the myocardial protein. In experiments on dogs, there were found such regularities in the change in the concentration of AA in the arte- rial blood and in the coronary sinus: in the case of an acute infection, leucine and isoleucine are reliably found in the myocardium, so that it is not concentrated in the arterial blood. on the background of an euglikemichesky insulin clemp, hyperinsulinemia caused to a decrease in the concentration of all amino acids, except for alanine; adjusting the concentration of AA in blood plasma on the background of the infusion of AA and carrying out the insulin clamp of the supernatant to increase the appropriate BCAAs in the myocardium; at a 4-5-fold increase in the concentration of amino acid in the blood plasma against the background of infusion, the accumulation of BCAAs by the myocardium was significantly increased. Installed, BCAAs, L-leucine and L-valin sprinkle, followed by cardioplegic mixtures [18].

G. William et al. in an experiment on mice proved that the use of a diet enriched with leucine, significantly improves the structure and functional activity of the myocardium after myocardial infarction, as well as increases survival. In mice fed a leucine-enriched diet, 3.5 days after myocardial infarction, compensatory myocardial hypertrophy increased and the inflammatory process decreased, myocardial ATP levels increased, and fibrosis and apoptosis slowed [19].

BCAAs is characterized by an antiarrhythmic effect. L-leucine reduces the duration of ventricular fibrillation, L-valine - ventricular fibrillation and ventricular tachycardia. L-valine is characterized by an antihypertensive effect [19].

BCAAs inhibit markers of inflammation in heart failure and improve physical tone in the elderly with heart failure. Thus, antianginal therapy enhances the catabolism of BCAAs, which is a source of ATP in myocardial ischemia.

After treatment of patients with NA with concomitant DM type 2 on the background of nebivolol compared with patients receiving bisoprolol, threonine levels decreased significantly compared to treatment by $45.5 \%$ and became significantly lower by $42.2 \%$ compared with patients with with NA with concomitant DM type 2 receiving bisoprolol.

Threonine improves the condition of the cardiovascular system and liver. It is also in- 
volved in the synthesis of glycine and serine, which strengthen ligaments and all muscles, including the myocardium [20]. Glycine and serine are synthesized from threonine in the body. Threonine also regulates the transmission of nerve impulses by neurotransmitters in the brain and helps eliminate depression. Studies have shown that it can reduce wheat gluten intolerance. Vegetarians usually have a deficiency of this amino acid. At high loads, the body feels the need for energy, so in the anabolic phase, threonine consumption increases. Its effective use requires an appropriate amount of vitamins B3, B6 and magnesium [5].

Thus, such dynamics of threonine changes indicates enhanced intracellular metabolism of this AA as a substrate of the above-mentioned AA serine and glycine, which have a cardioprotective effect.

Significantly, in patients with NA with concomitant DM type 2 whose antianginal therapy included nebivolol, the level of ammonia in the blood plasma was normalized, which contributes to the normal acid-base balance of the blood of patients with NA and concomitant DM type 2 .

Thus, the study showed significant changes in the level of individual NSAIDs in the plasma of patients with NA with concomitant DM type 2 on the background of antianginal therapy. It should be noted that treatment with nebivaol as part of basic therapy contributed to a significantly better dynamics of the balance of NSAIDs in blood plasma compared with bisoprolol. It's known, that balance of essential amino acids in plasma is very important for the normal functioning of the human body. Therefore, nebivolol should be preferred to improve the efficacy of treatment of patients with NA and concomitant DM type 2. This is the priority of this study. The main problem is the high cost of studying the amino acid spectrum of blood and the lack of opportunity to study it in general practice.

\section{CONCLUSIONS}

1. In patients with NA with concomitant DM type 2 diabetes on the background of antianginal therapy, which included bisoprolol and nebivolol, there was a significant decrease in the amount of essential AA of plasma compared with $\mathrm{CG}$ and pre-treatment, indicating increased intracellular metabolism and essential AA in ischemia.

2. In patients with NA with concomitant DM type 2 on the background of antianginal therapy, which included nebivolol, the level of histidine remained at the physiological level, compared with pre-treatment significantly decreased levels of threonine and isoleucine, significantly increased levels of valine, normalized ammonia.

3. The dynamics of changes in the levels of individual essential AA of plasma, due to the mechanisms of their metabolic transformations, in patients with NA with concomitant DM type 2 indicates greater effectiveness of nebivolol and the feasibility of its prescription in complex of a basic antianginal therapy.

\section{REFERENCES}

1. Sahanda IV. Phytotherapy 2018; 1: 56-58. https://doi. org/10.30525/978-9934-588-44-0/25.

2. Altunina NV. Clin Endocrinol Endocrine Surg 2015; 3(51): 30-35. https://doi.org/10.24026/1818-1384.3(51). 2015.75064 .

3. Ostroumova OD, Goloborodova IV, Fomina VM Kardiovaskuljarnaja terapija i profilaktika 2018;17(4): 81-93. https://doi.org/10.15829/1728-8800-2018-4-81-94.

4. Skala LV, Myshanich GI, Skala OV, et al. Int J Endocrinol 2018; 14(3). http://doi.org/10.22141/2224-0721.14. 3.2018.136418.

5. Sinkeev MS, Skvortsov YI, Bogdanova TM, Skvor tsov K.Yu. Int J Applied Fundamental Res 2014; 11(3): 480-484, available at: https://www.applied-research.ru/ $\mathrm{ru} /$ article/view?id $=616$.
6. Belikova YO. Ukr Sci Med Youth J 2017; 2(103): 10-14.

7. Bogdan TV, Lyzogub VG. Metabolism of amino acids in myocardial ischemia, Kiev, 2016: 207 p.

8. Huang Y, Zhou M, Sun H, et al. Cardiovasc Res 2011; 90: 220-223. https://doi.org/10.1093/cvr/cvr070.

9. Abduvaliev AA, Zohidov ZM, Nishantaev MK, et al. Uspekhi Sourem Nat Sci 2013; 9: 11, available at: http:// www.natural-sciences.ru/ru/article/view?id=32752.

10. Dobrovolska RA, Goshovska YuV, Szymanska TV, Sagach VF. Visn He Honey Un-tu 2014; 18(2): 372-375.

11. Cheonq SH, Moon SH, Lee SJ, et al. Adv Exp Med Biol 2013; 776: 167-177. https://doi.org/10.1007/978-1-46146093-0_17. 
12. Montalescot Gilles. Eur Heart J 2013; 34(38): 2949 3003. https://doi.org/10.1093/eurheartj/eht296.

13. Moshkovska YO. Medicines of Ukraine 2015; 190(4): 42-46.

14. Zavalska TV. Reports of the NAS of Ukraine 2015; 5: 173-177.

15. Lyzogub VG, TV Zavalska, VV Bogdan, DM Zhornichenko. Reports of the NAS of Ukraine 2015; 6: 167-174.

16. Severin ES. Biochemistry, Moskva, 2003: 779 p.
17. Gubergrits NB, Golubova OA, Lukashevich GM. Modern Gastroenterol 2012; 64: 114-121.

18. Lyzogub VG, Zavalska TV, Savchenko OV, Tyravska YuV. Lik Right Doctors Case 2013;5: 22-27.

19. Witham WG, Yester KA, McGaffin KR. Metabolism 2012. https://doi.org/10.1016/j.metabol.2012.07.02.

20. Shevchenko VP. Clinical Nutrition, Moskva, 2009: 256 p.

\section{THE ROLE OF BETA-BLOCKERS IN VETIANGINAL THERAPY IN THE CORRECTION OF VIOLATIONS OF THE AMINO ACID SPECTRUM IN PATIENTS WITH UNSTABLE ANGINA WITH CONCOMITANT DIABETES MELLITUS}

Bohdan T. V., Lizogub V. G., Sobol V. O., Bohdan V. V.

Bogomolets National Medical University, Kyiv, Ukraine taviza@mail.ua

The purpose of the study: to study the effect of bisoprolol and nebivolol on the spectrum of essential blood plasma AK in patients with concomitant diabetes mellitus (DM) type 2 in order to optimize drug treatment of this pathology in the future.

Material and methods. The study involved 70 patients with NA with concomitant DM type 2, which was divided into two groups: group I (37 patients) as part of basic antianginal therapy received bisoprolol, group II (33 patients) received nebivolol. The control group (CG) consisted of 18 healthy individuals. All patients were tested for irreplaceable blood plasma AA by ion exchange liquid chromatography on an automatic analyzer AK T-339 produced by "Microtechna» (Czech Republic, Prague) at the Institute of Biochemistry named after OV Palladin NAMS of Ukraine. The following essential AAs were identified: arginine, valine, histidine, isoleucine, leucine, lysine, methionine, threonine, phenylalanine. Examination of patients was performed at the beginning of treatment and after 20 days.

Results. It was determined that in patients with NA with concomitant DM type 2 under the influence of antianginal therapy in both groups significantly decreased the total amount of irreplaceable AA compared with control group, indicating an increase in intracellular metabolism as a compensatory response in coronary circulation. It should be noted that in patients of group II, in contrast to patients of group I, under the influence of treatment the level of histidine remained normal. The level of threonine significantly decreased compared to CG and the rate of patients in group I, the level of valine significantly increased compared to pre-treatment, the level of isoleucine significantly decreased compared with CG and with the rate of patients of group I. Importantly, ammonia levels returned to normal under the influence of basic therapy, which included nebivolol.

Conclusion. The dynamics of changes in the levels of individual irreplaceable AA blood plasma, due to the mechanisms of their metabolic transformations in patients with NA with concomitant DM type 2 indicates greater effectiveness of nebivolol and the feasibility of its prescription in complex of a basic antianginal therapy.

Key words: non-stable angina, diabetes mellitus, amino acid, bisoprolol, nebivolol. 


\section{МІСЦЕ БЕТА-АДРЕНОБЛОКАТОРІВ У СКЛАДІ АНТИАНГІНАЛЬНОÏ ТЕРАПІІ В КОРЕКЦІЇ ПОРУШЕНЬ СПЕКТРУ НЕЗАМІННИХ АМІНОКИСЛОТ ПЛАЗМИ КРОВІ У ХВОРИХ НА НЕСТАБІЛЬНУ СТЕНОКАРДІЮ З СУПУТНІМ ЦУКРОВИМ ДІАБЕТОМ}

Богдан Т. В., Лизогуб В. Г., Соболь В. О., Богдан В. В.

Національний медичний університет імені О. О. Боголольия, м. Киӥв, Украӥна taviza@mail.ua

Мета дослідження: вивчити вплив бісопрололу та небівололу на спектр незамінних АК плазми крові у хворих на НС з супутнім цукровим (ЦД) 2 типу з метою оптимізації медикаментозного лікування ціеї патології в подальшому.

Матеріал і методи. У дослідженні брали участь 70 пацієнтів на НС з супутнім ЦД 2 типу, яких розподілено на дві групи: I група (37 хворих) у складі базисної антиангінальної терапії приймали бісопролол, II група (33 хворих) приймали небіволол. Контрольну групу (КГ) складали 18 здорових осіб. Усім хворим визначали незамінні АК плазми крові методом іонообмінної рідинно-колонкової хроматографії на автоматичному аналізаторі АК Т-339 виробництва «Мікротехна» (Чехія, Прага) в Інституті біохімії ім. О. В. Палладіна НАМН України. Ідентифікували наступні незамінні АК: аргінін, валін, гістидин, ізолейцин, лейцин, лізин, метіонін, треонін, фенілаланін. Обстеження хворих проводили на початку лікування та через 20 днів.

Результати дослідження. Визначено, що у хворих на НС з супутнім ЦД 2 типу під дією антиангінальної терапії в обох групах достовірно зменшилася загальна сума незамінних АК порівняно з КГ, що свідчить про посилення внутрішньоклітинного метаболізму, як компенсаторної реакції в умовах порушення коронарного кровообігу. Слід відмітити, що у хворих II групи, на відміну від хворих I групи, під дією лікування на нормальному рівні утримався рівень гістидину, достовірно зменшився порівняно з КГ і показником хворих I групи рівень треоніну, достовірно підвищився порівняно 3 показником до лікування рівень валіну, достовірно зменшився порівняно з КГ та з показником хворих I групи рівень ізолейцину. Важливо, шо під впливом базисної терапії, що включала небіволол, нормалізувався рівень аміаку.

Висновок. Динаміка змін рівнів окремих незамінних АК плазми крові, зважаючи на механізми їх метаболічних перетворень, у хворих на НС з супутнім ЦД 2 типу свідчить про більш ефективніший вплив небівололу, що обгрунтовуе доцільність призначення цього лікарського засобу у складі базисної антиангінальної терапії з метою оптимізації медикаментозної корекції ціеї патології.

К л юч о ві с ло в а : нестабільна стенокардія, цукровий діабет, амінокислота, бісопролол, небіволол.

Богдан Т. В.

ORCID https://orcid.org/0000-0002-6441-1410

Лизогуб В. $Г$.

ORCID https://orcid.org/0000-0003-3603-7342

Соболь В. $\mathrm{O}$.

ORCID https://orcid.org/0000-0003-3815-4577

Богдан В. В.

ORCID https://orcid.org/0000-0003-3262-892X 